\title{
Implementasi Pendidikan Seks bagi Remaja dalam Perspektif Islam dan Psikologi Pendidikan
}

\author{
Jaja Suteja ${ }^{1}$, Komariah ${ }^{2}$ \\ ${ }^{1}$ Program Studi Bimbingan Konseling Islam, Fakultas Ushuluddin Adab dan Dakwah, \\ IAIN Syekh Nurjati Cirebon \\ Email Penulis ${ }^{1}$ : jajasuteja_iain@yahoo.co.id \\ ${ }^{2}$ SMA Negeri 1 Astanajapura Kab. Cirebon \\ Email Penulis 22: komariah81@gmail.com
}

\begin{abstract}
Abstrak
Maraknya penyimpangan-penyimpangan seksual di kalangan remaja yang terjadi di masyarakat merupakan suatu fenomena alamiah yang tidak bisa dihindari baik bagi orang tua, guru, kepala sekolah, tokoh agama maupun masyarakat. Hal ini disebabkan, karena kurangnya pembinaan dan bimbingan secara khusus oleh pihakpihak terkait terutama bimbingan dari kedua orang tuanya. Pendidikan seks yang benar perlu diajarkan oleh setiap orang tua kepada anak-anaknya sejak anak mengenal lingkungan, sampai menginjak dewasa. Pendidikan seks bagi anak dan remaja tidak harus merasa ditabukan lagi sepanjang pada garis yang telah ditentukan oleh kaidahkaidah Islam dan norma yang berlaku di masyarakat.Pendidikan seks banyak dikaji oleh berbagai tokoh intelektual muslim. Sebagian besar, berpendapat bahwa penerapan pendidikan seks bagi remaja penting untuk diterapkan dalam kehidupan sehari-hari, karena pendidikan seks merupakan salah satu solusi alternatif dalam mengurangi perilaku penyimpangan-penyimpangan seksual khususnya di kalangan remaja. Kesimpulan dari penelitian ini adalah bahwa pendidikan seks bagi remaja dalam tinjauan psikologi pendidikan Islam sangat penting untuk diterapkan dan dilaksanakan oleh para orang tua, guru, dan para pendidik lainnya baik di rumah maupun di sekolah. Karena dengan adanya pendidikan seks, bagi remaja akan mampu mengurangi terjadinya penyimpangan-penyimpagan seksual yang sering terjadi di kalangan remaja. Pendidikan seks ini tidak mengajarkan tentang bagaimana caranya berhubungan intim antar lawan jenis khususnya kepada para remaja, melainkan merupakan bagian dari upaya preventif dalam mencegah penyimpanganpenyimpangan yang terjadi di kalangan remaja, termasuk di dalamnya penyimpangan seksualitas.
\end{abstract}

Kata Kunci: Pendidikan Seks; Remaja; Perspektif Islam; Psikologi Pendidikan. 


\section{PENDAHULUAN}

Pergaulan bebas di kalangan remaja saat ini telah menjadi budaya dan kebiasaan bagi anak remaja, hampir setiap remaja yang melakukannya tidak mempunyai rasa malu lagi terhadap orang lain yang menyaksikannya, bahkan sebagian dari mereka justru merasa bangga melakukan perbuatan tersebut. Kehidupan remaja dengan berbagai permasalahannya menarik untuk dibicarakan, karena masa remaja merupakan masa transisi antara masa anak-anak ke masa dewasa. Banyak masalah-masalah yang dihadapi oleh generasi remaja khususnya yang berkaitan dengan masalah seks. Adanya anggapan bahwa seks itu merupakan masalah yang tabu dan kotor untuk diperbincangkan dan tidak layak untuk diajarkan kepada anak ataupun remaja, menyebabkan remaja mengenalnya secara alamiah, walaupun informasi yang di dapat remaja tersebut seringkali informasi seks yang salah atau tidak benar (al-'Adawy, 2016).

Masyarakat pada umumnya merasa tabu membicarakan hal-hal yang menyangkut masalah seksualitas. Hal ini karena dilandasi oleh faktor budaya dan sosial masyarakat yang heterogen sehingga melarang pembicaraan mengenai seksualitas di depan umum (publik). Masalah seks ini dianggap sebagai sesuatu yang porno dan aib, sifatnya sangat pribadi (privasi) tidak perlu diungkapkan kepada orang lain. Selain itu, pengertian seksualitas yang berkembang di masyarakat masih sangat sempit, pembicaraan tentang seksualitas seolah-olah hanya diartikan pada hubungan seks suami istri. Padahal secara etimologis seks itu memiliki arti jenis kelamin dan sama sekali tidak porno karena setiap orang tentu memiliki alat kelamin. Seksualitas sendiri artinya segala hal yang berhubungan dengan jenis kelamin, termasuk bagaimana cara kerjanya dan cara merawat kesehatannya agar tetap dapat berfungsi dengan baik (Baharits, 1998).

Para ulama terdahulu sebenarnya telah menggariskan persoalan sex education sejak awal mula seorang anak mendalami agama. Seperti halnya dalam pembahasan fikih bab tentang thaharah, di sini dibahas tentang tata cara mandi junub, bahkan kajian sampai pada masalah mimpi basah, hubungan suami istri dan haid. Hal inia menunjukkan bahwa sejak dini anak telah mengenal istilah-istilah itu secara tepat, dan itulah yang disebut sebagai Islamic sex education.

Akibat masyarakat tidak memahami masalah seks, terutama orang tua terhadap anaknya, mengakibatkan terjadinya berbagai penyimpangan-penyimpangan seksual baik itu free seks, kumpul kebo (samen leven), hamil di luar nikah, homo seksual dan perkosaan. Penyimpangan-penyimpangan seksual saat ini banyak terjadi di tengah-tengah masyarakat. Fenomena ini secara otomatis sangat mengkhawatiran berbagai pihak, baik itu guru, pemerintah, tokoh masyarakat terlebih lagi adalah orang tua. Hampir setiap waktu dan setiap malam pemandangan erotis hampir menjadi menu sehari-hari, di televisi, majalah, tabloid, bahkan di jalan-jalan bisa dengan langsung menyaksikan orang yang mengenakan pakaian yang mengumbar aurat dan mengundang birahi dengan alasan mengikuti mode dan perkembangan zaman. Belum lagi kemajuan teknologi juga turut berperan dalam mengekspolitasi seks hingga menembus dunia anak dan remaja, sebagian 
besar remaja memperoleh pengetahuan seks dari film bioskop, VCD porno, komik, dan internet (Arna, 2005).

Secara akademik, pendidikan seks bagi remaja, bukanlah suatu pelajaran untuk bagaimana para remaja melampiaskan nafsu seksualnya, melainkan untuk memberikan pelajaran dan informsi yang benar tentang seputar permasalahan seksualitas termasuk di dalamnya kesehatan refroduksi remaja. Pendidikan seks ini penting bagi remaja, karena secara psikologis masa remaja merupakan masa yang rawan dan labil untuk mengambil sebuah keputusan, masa peralihan dari anak-anak menuju dewasa, sedangkan pada masa ini gejolak seksualitas remaja semakin tinggi.

Masalah seks pada remaja seringkali mencemaskan para orang tua, pemerintah, para ahli dan sebagainya. Karena apabila kurang mendapat perhatian dan didikan baik oleh orang tuanya secara langsung, ibu bapak gurunya, maupun pemerintah akan menyebabkan perilaku seksual remaja yang menjurus kepada pergaulan bebas dan penyimpangan seksual. Maraknya pergaulan bebas dalam hal ini seks bebas di kalangan remaja, sebagian besar kerena disebabkan oleh beberapa faktor. Faktor yang sangat berperan sekali dalam hal ini adalah dari faktor lingkungan keluarga yang kurang memberikan perhatian kepada anak-anaknya serta faktor lingkungan yang ikut mendukung pada persoala tersebut (Fathunaja, 2015).

\section{PEMBAHASAN}

\section{Pendidikan Seks dalam Persfektif Islam}

Pengertian pendidikan seks secara umum adalah suatu cara (sistem) atau sarana (alat) untuk mendidik, mengarahkan ataupun menggiring orang lain agar berperilaku seks yang baik dan benar. Perilaku seks yang baik adalah suatu perbuatan atau kegiatan seks, baik secara fisik maupun non fisik, dapat menimbulkan dan mengakibatkan kebaikan seks, baik bagi pelaku seks itu sendiri maupun bagi orang lain, sebagai akibat dari perilaku seks tersebut. Oleh karena itu, ketika membicarakan pendidikan seks selalu tidak terlepas dengan pembahasan kesehatan reproduksi yang ada pada diri manusia (Baharits, 1998).

Dalam membahas pendidikan seks, paling tidak ada enam prinsip dasar yang harus dikaji, antara lain:
a. Perkembangan manusia: anatomi reproduksi dan fisiologi.
b. Hubungan antar manusia: keluarga, teman, pacaran dan perkawinan.
c. Kemampuan personal: nilai, pengambilan keputusan, komunikasi dan negosiasi.
d. Perilaku seksual: abstinence dan perilaku seks lain.
e. Kesehatan seksual meliputi: kontrasepsi, pencegahan penyakit menular seksual (PMS), AIDS, aborsi, dan kekerasaan seksual.

f. Budaya dan masyarakat; peran gender, seksualitas dan agama.

Dari dimensi psikologis, seksualitas berhubungan erat dengan bagaimana menjalankan fungsi sebagai makhluk seksual, identitas peran jenis, dan perasaan terhadap 
seksualitas diri. Bila ditinjau dari dimensi sosial, hal ini menyoroti kepada bagaimana seksualitas itu diterjemahkan menjadi perilaku seksual yang muncul berkaitan dengan dorongan seksual. Dan dimensi kultural menunjukkan bagaimana perilaku seks menjadi bagian dari budaya yang ada di masyarakat. Dalam pandangan psikologi pendidikan Islam, pendidikan seks dapat diartikan sebagai pendidikan yang mengatur tentang gejala-gejala kejiwaan manusia khususnya yang berkaitan dengan perilaku seksual yang sesuai dengan fitrahnya agar dapat menjadi keluarga yang harmonis dan bahagia (Aziz, n.d.).

Pendidikan seks di dalam Islam tidak dapat disamakan dengan pendidikan seks menurut ilmu pengetahuan modern sebagaimana pendapat umum saat ini, karena pendidikan seks di dalam Islam tidak dapat diajarkan oleh seseorang kepada orang lain, baik secara sendiri-sendiri ataupun secara bersama-sama, tanpa mengacu kepada al-Qur'an dan al-Hadits. Ajaran Islam telah mengajarkan pendidikan seks sejak seseorang dilahirkan ke muka bumi hingga meninggalkan dunia ini, bahkan perilaku seks orang bertaqwa yang kelak menjadi penghuni surgapun diterangkan secara jelas dan menarik di dalam alQur'an. Islam mengatur cara pergaulan antara laki-laki dan perempuan dengan tuntutan dan pendidikan seks yang penuh kebijaksanaan, sehingga setiap muslim akan terpelihara dari perbuatan yang menimbulkan pelanggaran dan penyimpangan seks yang tidak diinginkan oleh orang tua maupun masyarakat.

Pada prinsipnya pendidikan seks dalam persfektif Islam bertujuan agar manusia mampu menyalurkan fitah manusianya untuk menciptakan keluarga sakinah, mawaddah, dan rahmah. Bagitu pentingnya masalah seksual, sehingga Islam benar-benar mengatur masalah seksual ini dari mulai masa kanak-kanak, remaja hingga dewasa yang kesemuanya ini merupakan dalam upaya menjaga dan melindungi kesucian seksual. Pendidikan seks dalam Islam ini diajarkan dalam rangka mempelajari mengenai hubungan seks antara lakilaki dengan perempuan secara perseorangan dengan mengacu kepada prinsip-prinsip dasar al-Qur'an dan al-Hadits. Jika cara perseorangan tidak mampu, maka dapat meminta diajarkan oleh muhrimnya yang sejenis, yaitu antara seorang anak dan orang tuanya atau dengan muhrimnya yang lain yaitu dengan paman, kakak, dan sebagainya yang sejenis.

Ajaran Islam banyak mengajarkan aturan-aturan yang berkenaan dengan masalah seksual ini di antaranya yaitu larangan hidup membujang, menjaga pandangan mata terhadap lawan jenis yang bukan muhrimnya, perlunya seorang wanita menutup aurat, larangan kawin dengan saudara sekandung, larangan berzina, dan sebagainya. Semua itu merupakan pedoman pendidikan seks yang telah dinyatakan dalam al-Qur'an dan Sunnah Nabi Muhammad SAW. Adanya pedoman pendidikan seks tersebut, sebagai konsekuensi logis dari pengakuan Islam terhadap naluri seksual dan sebagai bukti bahwa Islam menjunjung tinggi kesucian dan keluhuran dorongan-dorongan seksual pada manusia (Simanjuntak, 2013).

Sebagai umat Islam diharuskan untuk mengetahui sebanyak-banyaknya ayat alQur'an dan al-Hadits yang berhubungan dengan masalah seksual dan pendidikan seks. Umat Islam diperintahkan agar mempunyai kemampuan untuk menganalisa dalam masalah seks, yaitu dengan cara memilih antara informasi seks yang baik dan tidak baik, sehingga 
dapat mengetahui informasi yang pantas untuk dilaksanakan dan mana yang harus ditinggalkan.

Menurut Abdullah Nashih Ulwan dan Hasan Hathout (1986) menjelaskan bahwa di antara nilai-nilai pendidikan seks yang dapat diberikan oleh orang tua kepada anak-anak remajanya antara lain meliputi:

1. Membiasakan anak tidur terpisah dengan orang tua.

2. Mengajarkan etika meminta izin untuk masuk kamar.

3. Mendidik anak dan remaja agar menutup aurat dan berpakaian Islami.

4. Mendidik remaja agar menundukkan pandangan dan menjaga pandangan mata.

5. Mendidik remaja agar tidak berduaan dengan lawan jenis.

6. Mendidik agar menahan diri bila tidak mampu menikah (Abdullah, 2003).

Menurut Sayyid Muhammad Ridhawi dalam Yatimin (2003) ada tiga alasan mengapa pendidikan sek bagi anak remaja itu penting untuk dikaji dan dibahas yaitu:

1. Seluruh muslim sepakat bahwa setiap muslim wajib mengikuti syariat Islam dan syariat itu tidak hanya terbatas pada shalat, puasa, haji dan amal ibadah lainnya melainkan syariat Islam juga mengajarkan mengenai peraturan tentang seks.

2. Perlunya mempelajari seks Islam bagi kaum muslim merupakan sebuah keharusan yang harus dipelajari oleh seluruh umat Islam dalam upaya menghadapi pandanganpandangan seks Barat yang banyak bertentangan dengan Islam.

3. Anak-anak di dunia Barat memperoleh pendidikan seks yang berlebihan sampai ke ukuran yang tak terbayangkan oleh generasi yang sebelumnya. Oleh karena itu, sangat penting bagi orang tua zaman sekarang untuk mengetahui pengetahuan seks mana yang benar dan mana yang salah, mana yang harus dikerjakan dan mana yang harus ditinggalkan. Dalam hal ini, hanya orang tua muslim yang mengetahuinya yang akan mampu menghadapi masalah ini dengan benar dan bertanggung jawab.

Dalam ajaran Islam, yang memiliki tanggung jawab terhadap perkembangan seksual anak-anaknya adalah kedua orang tuanya. Menurut Nina Surtiretna dalam Abdullah (2003) menyatakan bahwa pendidikan seks dalam keluarga merupakan alternatif dalam membekali anak-anaknya mengenai informasi seks yang benar. Jadi orang tua harus membangun suasana keakraban, keterbukaan, dan komunikasi yang harmonis kepada anak-anaknya terutama membicarakan mengenai permasalahan-permasalahan seksual.

Dalam al-Qur'an banyak ayat-ayat yang membicarakan tentang bagaimana menjaga hubungan suami-istri, menjaga pandangan mata, menutupi aurat, proses penciptaan manusia, dan masalah-masalah yang ada keterkaitannya dengan masalah seksualitas manusia. Ketika seseorang melakukan tindakan-tendakan yang tidak sesuai ataupun bertentangan dengan al-Qur'an maupun al-Hadits maka sebagai konsekuensinya adalah dia menjadi orang berdosa dan sebagai ancamanannya adalah masuk ke dalam api neraka yang telah disediakan oleh Allah SWT. (Abdullah, 2003). Islam mengajarkan kepada orang tua 
dan guru, agar berterus terang kepada anak-anaknya baik laki-laki maupun perempuan tentang pendidikan seks menurut ilmu psikologi pendidikan maupun menurut ilmu keislaman. Hal ini seperti yang telah disampaikan tentang hukum memandang dan etika meminta izin.

\section{Pendidikan Seks bagi Remaja dalam Persfektif Psikologi Pendidikan}

Jenis pendidikan seks bagi remaja menurut persfektif psikologi pendidikan lebih dititik beratkan kepada persoalan nilai, etika, akidah akhlak, dan ibadah sehingga pendidikan ini memiliki keterkaitan yang sangat erat dengan materi pendidikan agama Islam. Oleh karenanya sangat penting jika remaja memperdalam pengetahuan agama Islam dalam upaya membentengi diri dari pengaruh pergaulan bebas dan penyimpangan seksual. Terdapat beberapa faktor yang mendasari maraknya pergaulan bebas dan penyimpangan seksual di kalangan remaja antara lain:

Pertama adalah faktor psikologis, yaitu faktor yang hubungannya dengan kondisi kejiwaan seseorang yang bisa merasakan senang dan tidak senang. Kondisi psikologis tersebut sangat berperan dalam menentukan kesehatan jiwa, sikap, tingkah laku, dan cara berfikir seseorang. Orang yang jiwanya terganggu, maka sikap, tingkah laku, maupun cara berfikirnya akan terganggu pula. Dalam hubungannya dengan itu, bahwa tingkah laku dan cara berfikir seseorang merupakan cermin dari kondisi psikologis manusia sendiri karena manusia diberikan fitrah berupa cipta, rasa dan karsa. Ketiganya merupakan suatu rangkaian yang bersatu tidak bisa dipisahkan. Selain itu, secara psikologis anak-anak remaja sangat mengharapkan terpenuhinya kebutuhan psikologis antara lain: kebutuhan kasih sayang, kebutuhan harga diri, kebutuhan rasa bebas, kebutuhan mengenal lingkungan, kebutuhan rasa aman, kebutuhan rasa sukses, kebutuhan biologis (seksual), kebutuhan sandang, pangan dan papan, serta kebutuhan pendidikan dan pengetahuan (Qibtiyah, 2006).

Kedua adalah faktor sosiokultural, yaitu faktor sosial dan kebudayaan sangat mempengaruhi terhadap tingkah laku seseorang. Dengan munculnya bentuk-bentuk kebudayaan maka akan dapat membawa pengaruh positif maupun negatif termasuk di dalamnya masalah seksual. Maraknya pergaulan bebas di kalangan remaja disebabkan karena faktor kebiasaan dan kebudayaan yang berkembang di kalangan anak-anak remaja itu sendiri.

Ketiga adalah faktor pendidikan dan keluarga, faktor pendidikan dan keluarga memiliki peranan yang signifikan terhadap kepribadian generasi remaja. Bahkan pendidikan dan keluarga merupakan peletak dasar terbentuknya kepribadian dalam pendidikan. Dalam hal ini faktor keteladanan dan pembiasaan oleh keluarga merupakan faktor penentu dalam peletak dasar kepribadian anak. Karena sikap dan tindakan orang tua dicontoh dan selanjutnya dibiasakan menjadi pola tingkah laku, cepat atau lambat menjadi pola dalam bertindak, sebagai wujud dari kepribadiannya. Oleh karena itu keluarga merupakan penanggung jawab paling besar di antara bandingkan dengan lembaga pendidikan, pemerintah maupun organisasi sosial masyarakat. Dalam hal ini, orang tua 
merupakan pemegang peranan yang sangat menentukan atas keadaan kepribadian anak di masa mendatang termasuk terjadinya penyimpangan seksual (Qibtiyah, 2006).

Adapun jenis-jenis pendidikan seks yang dapat dilaksanakan dan diberikan kepada remaja dalam tinjauan psikologi pendidikan antara lain:

\section{Pendidikan Seks Seumur Hidup}

Pendidikan jenis ini lebih diarahkan kepada bagaimana seorang anak mendapatkan pengetahuan-pengetahuan tentang seks sesuai dengan masanya dari mulai masa anakanak, remaja, hingga masa dewasa dan tua. Pada saat remaja seorang anak harus benar-benar mendapatkan pengetahuan yang luas terkait dengan pendidikan seks. Selain itu, pendidikan seks tidak hanya berakhir pada seorang anak menginjak masa remaja, tetapi harus dilanjutkan sampai ketika dewasa bahkan lanjut usia.

\section{Pendidikan Meminta Ijin (isti’zam)}

Pendidikan jenis ini adalah pendidikan yang diterapkan oleh syariat Islam yakni ketika anak sudah menginjak masa balig maka orang tua harus memberitahukan bahwa ada waktu-waktu tertentu yang seharusnya sang anak tidak boleh masuk ke dalam kamar orang tuanya atau pada saat akan masuk kamar ke dua orang tuanya maka sang anak tersebut harus mengetuk pintu terlebih dahulu sebagai perwujudan dari meminta ijin untuk masuk kamar. Ketika sang anak masuk kamar orang tuanya tanpa meminta ijin terlebih dahulu sedangkan pada saat itu orang tua sedang melakukan hubungan suami istri maka hal ini akan mempengaruhi terhadap perkembangan psikologis anak. Bahkan apa yang dilihat oleh sang anak akan selalu terkenang dan melekat dalam benak ingatannya. Sedangkan pandangan tersebut sangat membahayakan terhadap psikologis perkembangan emosionalnya. Dalam Islam tiga waktu yang dilarang seorang anak masuk ke dalam kamar orang tuanya adalah pada pagi hari sebelum shalat shubuh, pada siang hari setelah shalat dhuhur dan pada malam hari setelah shalat isya.

\section{Pendidikan untuk Menahan Pandangan dan Menutup Aurat}

Pendidikan jenis ini lebih dititikberatkan kepada agar remaja mampu menahan pandangannya dan mampu menutup aurat seluruh tubuhnya. Karena dengan menahan pandangan, maka akan mempu mengurangi nafsu syahwat yang sering muncul dalam pikirannya. Begitu pula dengan menutup aurat di samping dapat mempercantik diri bagi yang wanita tetapi juga mampu mengurangi dosa dan angka kejahatan yang terjadi di masyrakat seperti pelecehan seksual dan perkosaan. Secara pendekatan fikih bagi seorang perempuan hampir seluruh bagian anggota tubuhnya merupakan aurat, kecuali wajah dan telapak tangannya, walaupun ada pendapat sebagian ulama yang mengatakan bahwa seluruh anggota tubuhnya dari mulai ujung rambut sampai ujung kakinya adalah aurat yang hanya boleh ditampakkan dan diperlihatkan oleh muhrimnya. 


\section{Pendidikan untuk Menjauhkan Remaja dari Aktifitas Seksual}

Pendidikan jenis ini lebih diarahkan agar remaja dijauhkan dari segala bentuk aktifitas seksual baik melalui media seperti televisi, internet, ataupun yang lainnya termasuk dari aktifitas seksual kedua orang tuanya. Oleh karena itu aktifitas seksual yang dilakukan oleh orang tua hendaknya dilakukan di tempat rahasia dan tersembunyi. Hal itu dilatarbelakangi karena sang anak belum memahami dengan baik terhadap apa yang dilihatnya dan juga belum memahami tentang bahaya yang bakal ditimbulkan setelah melihat aktifitas seksual tersebut (Budisuari and Arifin, 2005).

\section{Pendidikan Pemisahan Tempat Tidur}

Pemisahan tempat tidur anak remaja merupakan kaidah pendidikan lain bagi keberhasilan pendidikan seksual. Melalui pemisahan ini, seorang remaja dijauhkan dari kamar orang tuanya yang mungkin suatu ketika orang tuanya sedang melakukan hubungan seksual. Selain itu pemisahan tidur antara anak laki-laki dan perempuan harus dilakukan sejak dini untuk menghindari sentuhan-sentuhan badan yang dapat menyebabkan rangsangan seksual. Seharusnya setiap anak memiliki kamar tidur sendiri dengan berbagai perlengkapannya, bahkan orang tuanya tidak selayaknya mengatur lebih jauh mengenai penataan ruangan tempat tidurnya karena pada gilirannya sang anak akan jauh lebih bersifat mandiri dan dapat menumbuhkan rasa kebebasannya.

\section{Pendidikan tentang Larangan terhadap Tindakan Erotis}

Syariat Islam, mempertegas setiap tindakan-tiondakan erotis yang dapat membangkitkan gairah seks pada anak-anak dan remaja karena dengan melihat tindakan-tindakan erotis tersebut dapat menimbulkan nafsu syahwat yang tidak dapat terkontrol dan terkendalikan oleh anak-anak remaja. Sehingga dapat menjerumuskan anak remaja ke jurang perzinahan bahkan pemerkosaan. Islam memerintahkan pentingnya menjauhkan anak dari melihat langsung aktifitas seksual, selain itu pendidikan dan pembiasaan untuk mengendalikan diri dari rangsangan-rangsangan seks dan menanamkan aturan-aturan syariat dalam memandang dan menutup aurat di antara orang tua dan anak, orang dewasa dan anak-anak laki-laki dan perempuan, bertujuan untuk menjauhkan anak terutama anak usia mumayyiz dari setiap tindakan erotis (al-'Adawy, 2016).

\section{Pendidikan tentang Pernikahan Usia Dini}

Jenis pendidikan ini lebih terfokus pada tindakan preventif sebelum terjadinya perzinahan, pemerkosaan maupun tindakan-tindakan penyimpangan yang lainnya. Para pakar psikologi pendidikan dan seksiologi menganjurkan agar menempuh dan menyelesaikan pendidikan seksual dengan berbagai model dan metodenya termasuk pendidikan tentang pernikahan usia dini. Sebab, pernikahan usia dini merupakan solusi yang legal dan diperkenankan bagi anak usia balig yang tidak mampu mengendalikan dorongan seksualnya agar tidak dapat memuaskannya tanpa melanggar ketentuan hukum atau menghadapi kritikan masyarakat. Bahkan solusi itu memberikan ketenangan jiwa dan mendatangkan penghargaan dari orang lain. 
Oleh karena itu sebagian pakar pendidikan memutuskan ditempuhnya pernikahan usia dini sebagai sebuah langkah pencegahan dan penyembuhan sekaligus upaya dalam mengurangi penyimpangan yang sering terjadi di kalangan remaja (al-'Adawy, 2016).

\section{Implementasi Pendidikan Seks Bagi Remaja dalam Persfektif Psikologi Pendidikan}

Implementasi pendidikan seks bagi remaja dalam persfektif psikologi pendidikan bertujuan sebagai pendidikan moral atau akhlak agar remaja tidak terjerumus ke pergaulan bebas. Pendidikan seks patut diajarkan oleh orang tua dan para pendidik di sekolah sesuai dengan tahapan psikologis pertumbuhan dan perkembangan peserta didik, antara lain beberapa tahap berikut:

1. Pada usia antara 7-10 tahun anak diajari tentang sopan santun meminta ijin masuk rumah dan kamar termasuk di dalamnya sopan santun dalam hal memandang.

2. Pada usia 10-11 tahun yang namanya pubertas anak harus dijauhkan dari hal-hal yang membangkitkan birahi.

3. Pada usia antara 14-16 tahun yang disebut dengan masa remaja anak diajari etika bergaul dengan lawan jenis bila ia sudah matang menempuh perkawinan.

4. Setelah melewati usia remaja, yang disebut dengan usia pemuda anak diajari etika menahan diri bila ia tidak mampu menikah (Abdullah, 2003).

Remaja adalah kelompok usia sedang mengalami masa pubertas, karena pada masa ini pertumbuhan fisik dan perkembangan emosi dalam dirinya mengalami peningkatan. Untuk remaja putri biasanya ditandai dengan datangnya haid dan bagi remaja putra ditandai dengan datangnya mimpi basah. Pada masa ini remaja sedang dalam masa yang sangat labil. Para orang tua dan guru sebagai pendidik bagi anak-anaknya sudah seharusnya mengetahui perubahan yang terjadi pada anaknya tersebut karena dengan mengetahui perubahannya akan mampu mendidik dan mengarahkan para remaja tersebut ke jalan yang lebih baik. Di antara perubahan-perubahan yang harus diketahui oleh para orang tua /guru antara lain:

Pertama, perubahan fisik, yaitu perkembangan anggota tubuh. Perubahan-perubahan yang terjadi dapat mempengaruhi kepribadian, tingkah laku dan emosional mereka. Perkembangan ini adakalanya tidak sama antara remaja yang satu dengan yang lainnya karena masing-masing anak dipengaruhi oleh berbagai faktor yang mengikutinya seperti makanan yang dimakan dan kehidupan di lingkungannya. Kedua, perkembangan mobilitas. Maksudnya ialah pergerakan badan dan keteramilan seperti menulis, melukis dan seni-seni tangan yang lain. Usia remaja dianggap sebagai usia yang sukar, karena sering terjadi perubahan-perubahan pertumbuhan fisik mereka.

Ketiga, perkembangan fisiologi yaitu perkembangan fungsi anggota badan, seperti sistem syaraf, nerveus system, detak jantung, tekanan darah, pernafasan, pencemaran, tidur, dan kelenjar endokrin yang mempengaruhi perkembangan. Keempat, perkembangan berfikir, yaitu perkembangan fungsi fikir seperti kecerdasan, ingatan, perhatian, khayalan, berfikir, dan pencapaian prestasi. Tahap remaja merupakan tahap akhir perkembangan 
intelektual dan dianggap sebagai tahap yang matang untuk kemampuan berfikir (Bertens, 2006).

Kelima, perkembangan seksual, yaitu perkembangan soksiologis remaja yang meliputi sistem reproduksi serta bentuk tingkah laku seksual. Perkembangan ini mempunyai gambaran yang sangat jelas pada tahap remaja, yaitu sebagai tanda perubahan masa kanak-kanak kepada masa remaja dan hal inipun disebabkan oleh perubahanperubahan biokimia yang muncul akibat rembesan hormon oleh kelenjar-kelanjar. Akibatnya dapat dilihat dari bentuk anggota refroduksi, dimana sistem ini mempunyai kemampuan menjalankan fungsinya untuk melahirkan anak.

Keenam, perkembangan emosional, yaitu perkembangan yang muncul dari perkembangan sikap emosionalnya seperti sikap rileks, kritis, riang, gembira, defresi, marah, takut, cemburu dan lain sebagainya. Pada tahap remaja, biasanya sikap emosional lebih diekspresikan dengan kekerasan, agresif bahkan tidak sesuai dengan stimulasi. Anak remaja biasanya mengalami kesukaran dalam mengendalikan diri sehingga emosinya menjadi tidak menentu karena tingkah laku mereka seperti mengalami transisi, antara sikap anak-anak dan sikap dewasa.

Ketujuh, perkembangan sosial. Sebagian besar anak remaja akan berusaha untuk mandiri dan menghindari ketergantungan kepada orang tua. Mereka berusaha untuk mencari hubungan baru dengan orang-orang lain yang berbagai usia. Mereka akan menjalin hubungan dengan anak-anak yang lebih muda dari mereka. Untuk memberikan perlindungan mereka juga akan menjalin hubungan dengan orang-orang yang lebih dewasa dari mereka, untuk dijadikan idola dan menyainginya. Mereka juga akan menjalin hubungan dengan orang-orang yang seusianya, untuk berbagi kecenderungan dan pengalaman (Azalia, 2015).

Para ahli psikologi berpendapat bahwa pelaksanaan pendidikan seks bagi remaja sangat penting disampaikan kepada para remaja untuk menjamin kebahagiaan hidup mereka setelah menikah. Pelaksanaan Pendidikan seks juga penting demi menjaga kestabilan situasi psikis saat mereka menjelang balig. Umumnya para remaja membutuhkan penjelasan seks yang Islami sebelum mereka menikah, serta pembekalan tentang kaidah-kaidah seks yang mereka butuhkan kehidupan rumah tangga di masa depan.

Jika para pendidik, orang tua, para ulama selalu menyampaikan pendidikan seks di rumah, di mesjid, di sekolah-sekolah dan ditempat-tempat lainnya, maka remaja yang menjelang balig dapat dihindarkan dari perilaku seks menyimpang. Mereka bisa disiapkan memasuki kehidupan baru. Tetapi apabila para pendidik, orang tua, tokoh ulama, pemerintah tidak berusaha menyampaikan pendidikan yang sangat penting ini dan tidak menjelaskan kaidah-kaidah seks menurut pandangan Islam, dikhawatirkan mereka akan mendapatkan pengetahuan tersebut dari orang-orang yang rendah akhlaknya.

Pelaksanaan pendidikan seks bagi remaja menurut prinsip-prinsip psikologi pedidikan dalam Islam, menurut Guidelines of Comprehensive sexuality Education dalam Qibtiyah (2006) dijelaskan paling tidak ada beberapa prinsip fundamental yang seharusnya diperhatikan ketika berbicara pendidikan seksualitas antara lain sebagai berikut: 
1. Setiap orang mempunyai harga diri.

2. Semua anak harus dicintai dan dijaga.

3. Remaja seharusnya melihat dirinya sebagai individu yang unik dan berharga dalam lingkungannya.

4. Seksualitas adalah sesuatu yang alami dan sehat dalam kehidupan.

5. Semua orang ada naluri seksualitas mencakup aspek fisik, etik, sosial, spiritual, psikologi dan emosi.

6. Setiap individu mengekspersikan seksualitasnya yang utama.

7. Orang tua seharusnya menjadi pendidik seksualitas yang pertama dan utama.

8. Dalam masyarakat yang plural, orang harus menghormati dan menerima keberagaman nilai dan kepercayaan tentang seksualitas yang ada di masyarakat.

9. Hubungan seksualitas seharusnya berdasarkan rasa saling menghormati bukan memaksa dan mengekspolitasi atau menindas.

10.Semua orang mempunyai hak dan kewajiban untuk bertanggung jawab akan pilihan sikap dan perilaku seksualnya.

11.Keterlibatan dalam perilaku seksual di usia dini sangat beresiko.

12.Menghindari hubungan seksual adalah cara yang paling efektif untuk menghindari kehamilan yang tidak diinginkan dan mencegah HIV AIDS.

13.Remaja yang terlibat dalam hubungan seksual membutuhkan informasi tentang layanan kesehatan.

Dalam prinsip-prinsip psikologi pendidikan, Islam mengajarkan kehidupan yang sempurna bagi penganutnya, oleh karena itu tidak bisa membicarakan masalah-masalah dalam Islam termasuk seksualitas tanpa mengaitkan prinsip-prinsip lain dalam Islam. Prinsip-prinsip ajaran Islam, mempercayai bahwa perilaku seksual tidak hanya bertujuan refroduktif semata, tetapi juga kenikmatan sebagaimana dijelaskan dalam al-Qur'an surat Al-Ruum ayat 21 yang mengatakan bahwa:

"Tanda-tanda kebesaran Allah adalah Allah yang telah menciptakan pasanganmu dari jenismu sendiri supaya kamu merasa tentram kepada-Nya dan Allah menjadikan rasa kasih sayang di antara kamu. Sesungguhnya pada yang demikian itu benar-benar terdapat tanda-tanda bagi kaum yang berfikir".

Prinsip lain adalah kepuasan seksual merupakan hak suami istri. Al-Qur'an menyebutkan bahwa: "istrimu adalah pakaian bagi suami dan suami adalah pakaian bagi istri ". (al-Baqarah: 187), selanjutnya: "Pergaulilah istrimu dengan cara yang makruf" (Al-Nisa : 19). Pelaksanaan pendidikan seks bagi remaja dapat diaplikasikan melalui pendidikan seks di keluarga dan pendidikan seks di sekolah. Pendidkan seks di keluarga/rumah disebabkan karena rumah adalah benteng utama dan pertama tempat anakanak dibesarkan melalui pendidikan termasuk pendidikan seks bagi anak-anaknya. 
Pendidikan seks di lingkungan keluarga dapat ditempuh melalui pembinaan, nasihat dan bimbingan dari kedua orang tuanya baik itu ayah maupun ibu. Walaupun tidak menutup kemungkinan pendidikan seks juga diberikan oleh kakak ataupun keluarga yang lainnya. Pendekatan pengajaran pendidikan seks dalam keluarga lebih ditekankan pada konstruksi nilai-nilai personal pada anak artinya anak dapat memperoleh pengetahuan seksnya sesuai dengan perkembangan kepribadian anak atau remaja tersebut. Adapun halhal yang perlu diajarkan kepada para remaja dilingkungan keluarga antara lain:

1. Bagaimana hubungan lawan jenis yang Islami.

2. Bagaimana proses terjadinya mimpi basah dan menstrulasi bagi anak laki-laki dan perempuan.

3. Tentang kesehatan reproduksi remaja.

4. Tentang berbagai penyakit menular seksual (PMS).

5. Tentang bahayanya NAFZA (Narkotika, Alkohol, Psikotropika dan Zat adiktif lainnya).

6. Tentang karakteristik dan masalah-masalah yang sering muncul pada remaja.

Metode pengajaran pendidikan seks untuk remaja di rumah (keluarga) yang paling tepat adalah menggunakan pendekatan metode tanya jawab dan metode diskusi. Metode tanya jawab adalah suatu metode di dalam memberikan pendidikan dan pengajaran dimana nantinya orang tua bertanya sedangkan anak-anaknya menjawab terhadap pertanyaan yang ditujukan kepadanya. Sedangkan metode diskusi adalah suatu metode yang dilakukan secara berkelompok dalam memecahkan masalah-masalah yang dihadapi remaja, akan tetapi metode ini berbeda dengan berdebat. Walaupun kedua metode tersebut sebenarnya hanya bersifat tambahan, karena sesungguhnya metode nasihat dan bimbingan dari orang tua jauh lebih dirasakan oleh anak-anaknya (al-'Adawy, 2016).

Pendidikan seks bagi remaja di sekolah dapat diajarkan oleh guru BK maupun oleh guru mata pelajaran sebagai motivasi tambahan kepada siswa-siswinya. Metode yang dilakukan untuk menyampaikan pendidikan seks tersebut bisa lebih bervariasi dari mulai ceramah, diskusi, pemecahan masalah, demontrasi, permainan (games), tayangan film motivasi, maupun dengan metode yang lainnya. Tujuan metode tersebut sebagai berikut:

1. Membantu para remaja untuk mengetahui tentang seputar kesehatan reproduksi remaja dan biologis seperti pertumbuhan, masa puber dan kehamilan.

2. Mencegah anak remaja dari tindakan kekerasan.

3. Mengurangi rasa bersalah, rasa malu, dan kecemasan akibat tindakan seksual.

4. Mencegah remaja perempuan di bawah umur dari bahaya kehamilan.

5. Mendorong hubungan baik dan harmonis antara teman.

6. Mencegah remaja di bawah umur terlibat dalam hubungan seksual (sexual intercaurse).

7. Mengurangi kasus infeksi melalui seks.

8. Membantu para remaja yang bertanya tentang peran laki-laki dan perempuan di masyarakat. 


\section{SIMPULAN}

Berdasarkan hasil pembahasan tentang pendidikan seks bagi remaja dalam tinjauan psikologi pendidikan islam, maka dapat ditarik kesimpulan bahwa Pendidikan seks dalam persfektif psikologi pendidikan sangat penting dan perlu diterapkan bagi para remaja, karena remaja adalah generasi penerus masa depan bangsa. Oleh karenanya Islam memandang bahwa pendidikan seks adalah fithrah manusia yang harus dijunjung tinggi kehormatannya. Pendidikan seks dalam Islam berbeda dengan pendidikan seks menurut ilmu pengetahuan modern, karena pendidikan seks dalam Islam semuanya harus bersumber dari al-Qur'an dan al-Hadits. Pendidikan seks dalam Islam bertujuan tidak sekedar memberitahukan informasi seks yang baik dan benar saja melainkan bertujuan untuk mencegah dan mengurangi berbagai penyimpangan-penyimpangan seksual yang terjadi di masyarakat khususnya yang dialami oleh para remaja. Selanjutnya, seorang pendidik dalam memberikan pendidikan seks kepada remaja, pendidik harus memiliki strategi pendidikan yang efektif dan efisien dalam penyampaiannya, sehingga dari apa yang disampaikannya itu dapat diterima dan dilaksanakan oleh peserta didik.

\section{DAFTAR PUSTAKA}

Abdullah, Haidar. (2003). Kebebasan seksual dalam Islam. Zahra Publishing House.

Adawy, Musthafa al-’. (2016). Fikih Pendidikan Anak: Membentuk Kesalehan Anak Sejak Dini. Qisthi Press.

Arna, Antarini Pratiwi. (2005). Kekerasan terhadap anak di mata anak Indonesia: hasil konsultasi anak tentang kekerasan terhadap anak di 18 provinsi dan nasional. Yayasan Pemantau Hak Anak.

Azalia, Mira Humaira. (2015). Perilaku Menyimpang Di Kalangan Remaja Di Panti Sosial Marsudi Putra Handayani Bambu Apus Jakarta Timur Juli. http://repository.uinjkt.ac.id/dspace/handle/123456789/27086.

Baharits, Adnan Hasan Shalih. (1998). Penyimpangan Seksual Pada Anak. Gema Insani.

Bertens, Kees. (2006). Psikoanalisis Sigmund Freud. Gramedia Pustaka Utama.

Budisuari, Made Asri, and Andryansyah Arifin. (2005). Pengembangan Model Kesehatan Reporduksi Remaja (KRR). Buletin Penelitian Sistem Kesehatan 8 (1 Juni). https://doi.org/10.22435/bpsk.v8i1 Jun.1831.

Fathunaja, Anji. (2015). Reorientasi Pendidikan Seks Terhadap Anak Usia Remaja Di Sekolah (Memadukan Sains dan Agama dalam Pembelajaran). JURNAL JPSD (Jurnal Pendidikan Sekolah Dasar) 1 (1):104-24. 
268 | Suteja \& Komariah - Implementasi Pendidikan Seks ...

Safrudin, Aziz. (n.d). Pendidikan Seks Perspektif Terapi Sufistik Bagi LGBT. Penerbit Ernest.

Qibtiyah, Alimatul. (2006). Paradigma Pendidikan Seksualitas: Perspektif Islam Teori Dan Praktik. Yogyakarta: Kurnia Kalam Semesta.

Simanjuntak, Bungaran Antonius. (2013). Harmonious Family: Upaya Membangun Keluarga Harmonis. Yayasan Pustaka Obor Indonesia. 